\title{
Apparent and standardized ileal digestibility of protein and amino acids of several field bean and pea varieties in growing pigs*
}

\author{
M. Kasprowicz and A. Frankiewicz ${ }^{1}$ \\ August Cieszkowski Agricultural University, \\ Department of Animal Nutrition and Feed Management \\ Wotyńska 33, 60-637 Poznań, Poland
}

(Received 17 May 2003; revised version 19 March 2004; accepted 16 June 2004)

\begin{abstract}
The apparent ileal digestibility of protein and amino acids of field beans (cv. Nadwiślański, Kodam, Martin and Optimal) and of peas (cv. Piast, Rola, Idol and Wiato) was determined by the indicator method using $\mathrm{Cr}_{2} \mathrm{O}_{3}$. The experiment was conducted in a double Latin square design $(5 \times 5$ and $4 \times 4)$ on nine barrows with an initial body weight of about $25 \mathrm{~kg}$ equipped with simple T-cannuale inserted into the terminal ileum. The only source of protein in the experimental diets was either field beans or peas, whereas in the control diet soyabean oilmeal. The digestibility of protein and of most amino acids was significantly lower in field beans and peas $(\mathrm{P}<0.05)$ than in soyabean oilmeal. No significant differences were found $(\mathrm{P}>0.05)$ in the digestibility of protein or amino acids among the tested varieties of field beans. Significant differences did, however, appear in the digestibility of protein and amino acids between white- and coloured-flowered pea varieties $(\mathrm{P}<0.05)$.

Standardized protein and amino acid digestibility of the studied varieties of field bean and peas was calculated. The coefficients of standardized digestibility were somewhat higher than those of apparent ileal digestibility.
\end{abstract}

KEY WORDS: pigs, ileal digestibility, field bean, pea

\footnotetext{
* Supported by the State Committee for Scientific Research, Grant No. 6 P06E 02920

${ }^{1}$ Corresponding author: e-mail: frank@jay.au.poznan.pl
} 


\section{INTRODUCTION}

The systems of feed formulation currently in use for pigs recommend taking into account the amino acids digested in the small intestine (NRC, 1998; Grala et al., 1999). When determining apparent ileal digestibility of protein and amino acids, endogenous nitrogen compounds are not factored in, although they constitute a significant pool of compounds excreted with faeces and have a relatively constant chemical composition (Jondreville et al., 1995). Losses of endogenous nitrogen are taken into account in modern standardized digestibility coefficients, which are a better indicator of the availability of amino acids in the gastrointestinal tract of pigs than apparent digestibility coefficients. The equations given by Degussa (2001) are used to calculate standardized digestibility coefficients.

Over the past years breeding has led to the registration of legume varieties having reduced levels of antinutrients, including tannins, ADF, and NDF (Gdala et al., 1992; Abrahamsson et al., 1993; Grala et al., 1993; Mariscal-Landin et al., 2002). Tannins form complexes with proteins, metal ions and other macromolecules, lowering their availability to animals (Abrahamsson et al., 1993). The tannins in field beans and peas lower protein and energy digestibility, reduce body weight gain and feed utilization by pigs (Selgado et al., 2002a). As the tannin content of the diet increases, the activity of digestive enzymes has been found to decrease, accompanied by development of disorders in liver and digestive tract functions (Jansman, 1993).

It may be presumed that the seeds of the new varieties of legumes, with reduced levels of antinutrients, may be an alternative to soyabean oilmeal in pig nutrition.

The objective of this study was to determine the apparent and standardized digestibility of the protein and amino acids of selected varieties of field beans and peas.

\section{MATERIAL AND METHODS}

\section{Protein sources}

The study was conducted using the field bean variety Nadwiślański (a traditional variety registered in 1955), and the recently registered varieties Kodam (conventional), Martin and Optimal (self-determinate), as well as pea varieties Piast and Rola (white-flowers) and Idol and Wiato (coloured-flowers). When choosing the varieties, their chemical composition, yield stability, protein yield per hectare (Wiatr, 1999) and antinutrient content were taken into account. 


\section{Animals, diets and feeding}

The experiment was conducted on 9 Złotnicka White barrows with an average initial body weight of about $25 \mathrm{~kg}$. The animals were fitted with simple T-cannulae in the terminal ileum according to the method of van Leeuwen et al. (1991).

The animals were fed in a double Latin square design $(5 \times 5$ and $4 \times 4)$ with semisynthetic mixtures in which the only source of protein was legume seeds or soyabean oilmeal (SBM) (control group). Digestibility was determined by the indicator method using $\mathrm{Cr}_{2} \mathrm{O}_{3}$. The feed was given dry in two rations at 7.00 and 19.00 .

The chemical composition of the protein feeds is given in Table 1, their amino acid composition in Table 2 and feed composition in Table 4.

\section{Experimental procedure}

The study period was composed of a nine-day adaptation period and a two-day experimental period. In the experimental period, samples of ileal contents (about $40 \mathrm{~g}$ ) were collected every $4 \mathrm{~h}$, frozen immediately and stored until chemical analysis. Fresh samples were used for determination of dry matter; the remaining components were assayed in freeze dried samples.

TABLE 1

Chemical composition of soyabean meal, field bean and pea seeds, \% DM

\begin{tabular}{|c|c|c|c|c|c|c|c|c|c|}
\hline & $\begin{array}{l}\text { Dry } \\
\text { matter }\end{array}$ & $\begin{array}{l}\text { Crude } \\
\text { protein }\end{array}$ & $\begin{array}{c}\text { Crude } \\
\text { ash }\end{array}$ & $\begin{array}{c}\text { Crude } \\
\text { fibre }\end{array}$ & $\begin{array}{l}\text { Ether } \\
\text { extract }\end{array}$ & $\begin{array}{l}\mathrm{N} \text {-free } \\
\text { extra- } \\
\text { ctives }\end{array}$ & $\mathrm{ADF}$ & NDF & $\begin{array}{r}\text { Tannins } \\
\mathrm{mg} / \mathrm{g} \\
\mathrm{DM}\end{array}$ \\
\hline Soyabean meal & 87.70 & 48.87 & 7.15 & 8.38 & 1.89 & 33.70 & 10.50 & 15.51 & - \\
\hline \multicolumn{10}{|l|}{ Field bean } \\
\hline Nadwiślański & 87.40 & $31.08^{\mathrm{b}}$ & 4.24 & 10.09 & 1.63 & $52.93^{\mathrm{a}}$ & 12.00 & 22.91 & 6.09 \\
\hline Kodam & 87.85 & $29.52^{\mathrm{ab}}$ & 3.47 & 8.27 & 1.43 & $57.25^{\mathrm{bc}}$ & 10.49 & 21.93 & 7.17 \\
\hline Martin & 86.79 & $30.43^{\mathrm{ab}}$ & 3.45 & 8.74 & 1.49 & $55.83^{\mathrm{b}}$ & 10.85 & 23.78 & 6.05 \\
\hline Optimal & 88.19 & $27.08^{a}$ & 4.21 & 8.42 & 1.53 & $58.40^{c}$ & 11.07 & 24.19 & 7.39 \\
\hline \multicolumn{10}{|l|}{ Pea } \\
\hline $\begin{array}{c}\text { Piast (white- } \\
\text { flowered) }\end{array}$ & 87.47 & 23.31 & 3.21 & 5.72 & 1.55 & $66.20^{\mathrm{b}}$ & 6.65 & 28.00 & $3.18^{\mathrm{a}}$ \\
\hline $\begin{array}{l}\text { Rola (white- } \\
\text { flowered) }\end{array}$ & 88.01 & 25.13 & 3.07 & 6.79 & 1.56 & $63.45^{\mathrm{a}}$ & 7.94 & 28.90 & $2.50^{\mathrm{a}}$ \\
\hline $\begin{array}{l}\text { Idol (colour- } \\
\text { flowered) }\end{array}$ & 88.01 & 25.90 & 3.34 & 6.62 & 1.19 & $62.95^{\mathrm{a}}$ & 8.16 & 29.20 & $4.56^{\mathrm{b}}$ \\
\hline $\begin{array}{l}\text { Wiato (colour- } \\
\text { flowered) }\end{array}$ & 88.23 & 24.13 & 3.29 & 6.43 & 1.23 & $64.93^{\mathrm{ab}}$ & 7.93 & 24.35 & $5.43^{\mathrm{b}}$ \\
\hline
\end{tabular}

a,b,c- values in rows destignated with different letters differ significantly at $\mathrm{P}<0.05$ 
TABLE 2

Amino acids composition of protein of soyabean meal, faba bean and pea seeds, $\mathrm{g} / 100 \mathrm{~g}$ protein

\begin{tabular}{|c|c|c|c|c|c|c|c|c|c|}
\hline & \multirow{3}{*}{$\begin{array}{c}\text { Soyabean } \\
\text { meal }\end{array}$} & \multirow{2}{*}{\multicolumn{4}{|c|}{ Faba bean }} & \multicolumn{4}{|c|}{ Pea } \\
\hline & & & & & & \multicolumn{2}{|c|}{$\begin{array}{c}\text { white- } \\
\text { flowered }\end{array}$} & \multicolumn{2}{|c|}{$\begin{array}{l}\text { coloured- } \\
\text { flowered }\end{array}$} \\
\hline & & $\begin{array}{l}\text { Nadwi- } \\
\text { ślański }\end{array}$ & Kodam & Martin & Optimal & Piast & Rola & Idol & Wiato \\
\hline Lys & 5.65 & 5.76 & 6.00 & 6.02 & 6.30 & 6.80 & 6.89 & 6.74 & 6.97 \\
\hline Met & 1.18 & 0.87 & 0.74 & 0.76 & 0.70 & 0.75 & 0.74 & 0.79 & 0.81 \\
\hline Thr & 3.56 & 3.55 & 3.53 & 3.58 & 3.65 & 3.59 & 3.60 & 3.64 & 3.45 \\
\hline Arg & 6.32 & 8.00 & 8.20 & 8.80 & 7.90 & 8.59 & 7.71 & 8.41 & 8.11 \\
\hline His & 3.00 & 3.15 & 3.02 & 2.69 & 2.66 & 3.48 & 3.34 & 3.37 & 3.34 \\
\hline Ile & 3.54 & 3.74 & 3.50 & 3.57 & 3.62 & 2.98 & 3.20 & 3.02 & 3.29 \\
\hline Leu & 6.62 & 7.34 & 6.94 & 7.13 & 7.16 & 6.58 & 6.36 & 6.42 & 6.66 \\
\hline Phe & 5.19 & 4.75 & 5.03 & 4.34 & 4.40 & 4.95 & 5.20 & 4.92 & 5.17 \\
\hline Val & 3.60 & 4.25 & 4.28 & 4.35 & 4.42 & 3.61 & 3.83 & 3.59 & 3.79 \\
\hline Ala & 4.67 & 4.34 & 4.15 & 4.23 & 4.32 & 4.08 & 4.64 & 3.98 & 4.55 \\
\hline Asp & 10.84 & 11.15 & 11.09 & 11.06 & 10.85 & 11.06 & 11.16 & 11.76 & 11.56 \\
\hline Cys & 1.84 & 1.21 & 1.21 & 1.23 & 1.37 & 1.41 & 1.21 & 1.18 & 1.21 \\
\hline Glu & 20.41 & 19.50 & 19.33 & 19.68 & 19.66 & 19.91 & 19.44 & 19.70 & 19.12 \\
\hline Gly & 3.67 & 3.83 & 3.93 & 3.89 & 4.16 & 4.00 & 3.91 & 3.95 & 3.73 \\
\hline Pro & 5.98 & 5.06 & 5.57 & 5.76 & 5.89 & 5.45 & 5.29 & 5.41 & 4.94 \\
\hline Ser & 4.97 & 5.07 & 4.90 & 4.88 & 4.93 & 5.55 & 4.68 & 4.53 & 4.77 \\
\hline Tyr & 3.95 & 3.38 & 3.49 & 2.98 & 3.00 & 3.35 & 3.60 & 3.57 & 3.52 \\
\hline
\end{tabular}

\section{Chemical analyses}

The basic chemical composition of feeds and ileal contents was determined according to AOAC (1996) procedures. Total protein was assayed by the Kjeldahl method using a Kjel Foss apparatus, crude fibre, ADF and NDF, by the van Soest procedure on a Tecator apparatus. The amino acid content was determined using a type AAA-339 Mikrotechnia amino acid analyser following hydrolysis of samples in $6 \mathrm{~N} \mathrm{HCL}$ at $105^{\circ} \mathrm{C}$ for $23 \mathrm{~h}$. The tannin content was determined according to Kuhla and Ebmeier (1981), $\mathrm{Cr}_{2} \mathrm{O}_{3}$ by the method of Saha and Gilbreath (1991) using a Carl Zeiss Jena AAS-3 spectrophotometer after wet mineralization of the samples.

Standardized ileal protein and amino acid digestibility coefficients were calculated on the basis of the equation and endogenous protein and amino acid losses given by Degussa (2001).

\section{Statistical analysis}

One-way analysis of variance was performed, the significance of differences between varieties was calculated using Duncan's test. The statistical analysis was performed using Statgraphics Plus ver. 5.1 software. 
TABLE 3

Composition of diets, $\%$

\begin{tabular}{lccc}
\hline \multirow{2}{*}{ Item } & \multicolumn{3}{c}{ Diet } \\
\cline { 2 - 4 } & control & field bean & pea \\
\hline Soyabean meal & 35 & - & - \\
Faba bean meal & - & 59 & - \\
Pea meal & - & - & 70 \\
Maize starch & 19 & 19 & 19 \\
Soya oil & 1 & 1 & 1 \\
Calcium phosphate & 2.4 & 1.8 & 2.1 \\
Limestone & 0.8 & 1.2 & 1.1 \\
NaCl & 0.4 & 0.4 & 0.4 \\
Premix & 1 & 1 & 1 \\
Sugar & 40.2 & 16.4 & 5.2 \\
$\mathrm{Cr}_{2} \mathrm{O}_{3}$ & 0.2 & 0.2 & 0.2 \\
\hline
\end{tabular}

TABLE 4

Composition and nutritive value of diets, $\%$

\begin{tabular}{|c|c|c|c|c|c|c|c|c|c|}
\hline \multirow{3}{*}{ Item } & \multirow{3}{*}{$\begin{array}{c}\text { Soyabean } \\
\text { meal }\end{array}$} & \multirow{2}{*}{\multicolumn{4}{|c|}{ Field bean }} & \multicolumn{4}{|c|}{ Pea } \\
\hline & & & & & & \multicolumn{2}{|c|}{$\begin{array}{l}\text { white- } \\
\text { flowered }\end{array}$} & \multicolumn{2}{|c|}{$\begin{array}{l}\text { coloured- } \\
\text { flowered }\end{array}$} \\
\hline & & $\begin{array}{l}\text { Nadwi- } \\
\text { ślański }\end{array}$ & Kodam & Martin & Optimal & Piast & Rola & Idol & Wiato \\
\hline $\begin{array}{c}\text { Metabolizable } \\
\text { energy, MJ }\end{array}$ & 13.45 & 13.60 & 13.60 & 13.60 & 13.60 & 13.60 & 13.60 & 13.60 & 13.60 \\
\hline Crude protein & 15.46 & 16.17 & 15.36 & 16.12 & 14.16 & 15.12 & 15.84 & 16.58 & 15.41 \\
\hline Crude ash & 5.64 & 5.49 & 5.17 & 4.98 & 5.37 & 5.36 & 5.78 & 5.47 & 5.43 \\
\hline Crude fibre & 2.90 & 4.60 & 4.51 & 3.89 & 3.90 & 3.37 & 4.09 & 3.77 & 4.07 \\
\hline Ether extract & 1.85 & 1.72 & 1.95 & 1.87 & 1.93 & 2.08 & 1.82 & 1.84 & 1.90 \\
\hline Reducing sugars & 26.87 & 13.82 & 12.89 & 13.19 & 13.08 & 7.15 & 6.03 & 6.28 & 5.73 \\
\hline $\mathrm{ADF}$ & 3.67 & 5.83 & 6.12 & 5.67 & 6.39 & 4.07 & 5.38 & 5.17 & 4.99 \\
\hline NDF & 5.59 & 11.08 & 10.59 & 11.09 & 10.58 & 13.57 & 14.89 & 13.54 & 13.64 \\
\hline Lys & 0.86 & 1.00 & 0.94 & 0.96 & 0.87 & 1.02 & 1.06 & 1.12 & 1.07 \\
\hline Met & 0.18 & 0.13 & 0.11 & 0.12 & 0.09 & 0.11 & 0.12 & 0.13 & 0.12 \\
\hline Thr & 0.55 & 0.56 & 0.53 & 0.56 & 0.51 & 0.53 & 0.57 & 0.58 & 0.55 \\
\hline
\end{tabular}

\section{RESULTS}

The apparent ileal digestibility of protein and most amino acids was significantly $(\mathrm{P}<0.05)$ lower than that of soyabean oilmeal (SBM) (Table 5) and did not significantly differ $(\mathrm{P}>0.05)$ among varieties. The average digestibility of lysine, threonine, and methionine was $11,13.6$ and 10 percentage points, respectively, 
TABLE 5

Mean coefficients of apparent ileal digestibility of protein and amino acids in soyabean meal and field bean seeds, $\%$

\begin{tabular}{lccccc}
\hline \multirow{2}{*}{ Item } & $\begin{array}{c}\text { Soyabean } \\
\text { meal }\end{array}$ & \multicolumn{4}{c}{ Field bean } \\
\cline { 3 - 6 } & Nadwiślański & Kodam & Martin & Optimal \\
\hline Crude protein & $83.9^{\mathrm{b}}$ & $73.3^{\mathrm{a}}$ & $72.5^{\mathrm{a}}$ & $72.3^{\mathrm{a}}$ & $73.9^{\mathrm{a}}$ \\
Lys & $87.1^{\mathrm{b}}$ & $77.0^{\mathrm{a}}$ & $76.4^{\mathrm{a}}$ & $74.1^{\mathrm{a}}$ & $76.8^{\mathrm{a}}$ \\
Met & $87.3^{\mathrm{b}}$ & $63.5^{\mathrm{a}}$ & $53.8^{\mathrm{a}}$ & $59.4^{\mathrm{a}}$ & $56.2^{\mathrm{a}}$ \\
Thr & $82.0^{\mathrm{b}}$ & $68.8^{\mathrm{a}}$ & $68.7^{\mathrm{a}}$ & $66.4^{\mathrm{a}}$ & $69.7^{\mathrm{a}}$ \\
Arg & $91.3^{\mathrm{b}}$ & $85.7^{\mathrm{ab}}$ & $84.6^{\mathrm{ab}}$ & $84.8^{\mathrm{ab}}$ & $83.8^{\mathrm{a}}$ \\
His & $82.6^{\mathrm{b}}$ & $74.5^{\mathrm{ab}}$ & $70.1^{\mathrm{a}}$ & $67.9^{\mathrm{a}}$ & $72.3^{\mathrm{ab}}$ \\
Ile & $84.0^{\mathrm{b}}$ & $68.8^{\mathrm{a}}$ & $69.4^{\mathrm{a}}$ & $67.0^{\mathrm{a}}$ & $69.9^{\mathrm{a}}$ \\
Leu & $85.3^{\mathrm{b}}$ & $74.3^{\mathrm{a}}$ & $74.2^{\mathrm{a}}$ & $71.8^{\mathrm{a}}$ & $74.5^{\mathrm{a}}$ \\
Phe & $83.5^{\mathrm{b}}$ & $68.0^{\mathrm{a}}$ & $67.6^{\mathrm{a}}$ & $64.4^{\mathrm{a}}$ & $67.8^{\mathrm{a}}$ \\
Val & $82.6^{\mathrm{b}}$ & $70.3^{\mathrm{a}}$ & $70.1^{\mathrm{a}}$ & $67.9^{\mathrm{a}}$ & $71.7^{\mathrm{a}}$ \\
Ala & $79.2^{\mathrm{b}}$ & $64.6^{\mathrm{a}}$ & $63.0^{\mathrm{a}}$ & $62.9^{\mathrm{a}}$ & $67.5^{\mathrm{ab}}$ \\
Asp & $85.8^{\mathrm{b}}$ & $74.4^{\mathrm{a}}$ & $75.5^{\mathrm{a}}$ & $73.5^{\mathrm{a}}$ & $75.6^{\mathrm{a}}$ \\
Cys & $86.3^{\mathrm{b}}$ & $71.2^{\mathrm{a}}$ & $69.5^{\mathrm{a}}$ & $66.7^{\mathrm{a}}$ & $70.0^{\mathrm{a}}$ \\
Glu & $89.5^{\mathrm{b}}$ & $79.5^{\mathrm{a}}$ & $81.4^{\mathrm{a}}$ & $79.9^{\mathrm{a}}$ & $81.4^{\mathrm{a}}$ \\
Gly & $79.2^{\mathrm{b}}$ & $61.7^{\mathrm{a}}$ & $62.3^{\mathrm{a}}$ & $61.5^{\mathrm{a}}$ & $64.5^{\mathrm{ab}}$ \\
Pro & $86.3^{\mathrm{b}}$ & $55.4^{\mathrm{a}}$ & $55.8^{\mathrm{ab}}$ & $63.0^{\mathrm{ab}}$ & $57.7^{\mathrm{ab}}$ \\
Ser & $85.8^{\mathrm{b}}$ & $73.6^{\mathrm{a}}$ & $73.7^{\mathrm{a}}$ & $73.6^{\mathrm{a}}$ & $75.0^{\mathrm{a}}$ \\
Tyr & $80.6^{\mathrm{b}}$ & $68.0^{\mathrm{ab}}$ & $60.4^{\mathrm{a}}$ & $64.3^{\mathrm{a}}$ & $65.1^{\mathrm{a}}$ \\
\hline
\end{tabular}

a,b- values in rows destignated with different letters differ significantly at $\mathrm{P}<0.05$

lower than in SBM. No significant differences were found, however, between SBM and: field bean cv. Nadwiślański in the digestibility of arginine, histidine, and tyrosine; cv. Kodam and Martin, in the digestibility of arginine and proline; $\mathrm{cv}$. Optimal in the digestibility of alanine, glycine, and proline. The digestibility coefficients of proline and methionine were lowest.

The ileal digestibility of protein and some amino acids of peas were significantly lower $(\mathrm{P}<0.05)$ than in SBM (Table 6). The ileal digestibility coefficients of pea protein ranged from 75.2 to $80.5 \%$, with significant differences $(\mathrm{P}<0.05)$ between the white-flowered variety, Rola, and the coloured-flowered Idol. Differences in the digestibility of lysine of the cultivars Piast, Rola, Wiato, of arginine, glycine and cystine (Piast and Rola), histidine (Rola and Wiato), threonine, phenylalanine, alanine, aspartic acid, glutamic acid (Rola) did not differ significantly ( $\mathrm{P}>0.05)$ from the digestibility of these amino acids in soyabean meal.

Standardized ileal protein and amino acid digestibility coefficients (Table 7) differed from those given by Degussa (2001) only slightly in the case of field beans ( 2 to 4 percentage points), somewhat more in the case of peas (from 3 to 7 ), and most in relation to soyabean meal ( 9 percentage points). The greatest differences were found in the digestibility of lysine and threonine in peas and histidine in field beans. 
TABLE 6

Mean coefficients of apparent ileal digestibility of protein and amino acids in soyabean meal and pea seeds

\begin{tabular}{|c|c|c|c|c|c|}
\hline \multirow{2}{*}{ Item } & \multirow{2}{*}{$\begin{array}{c}\text { Soyabean } \\
\text { meal }\end{array}$} & \multicolumn{2}{|c|}{ White-flowered pea } & \multicolumn{2}{|c|}{ Coloured-flowered pea } \\
\hline & & Piast & Rola & Idol & Wiato \\
\hline Crude protein & $83.9^{\mathrm{c}}$ & $78.5^{\mathrm{ab}}$ & $80.6^{\mathrm{b}}$ & $75.2^{\mathrm{a}}$ & $78.4^{\mathrm{ab}}$ \\
\hline Lys & $87.1^{\mathrm{b}}$ & $83.3^{\mathrm{ab}}$ & $86.6^{\mathrm{b}}$ & $81.2^{\mathrm{a}}$ & $83.4^{\mathrm{ab}}$ \\
\hline Met & $87.3^{\mathrm{b}}$ & $65.4^{\mathrm{a}}$ & $65.6^{\mathrm{a}}$ & $62.6^{\mathrm{a}}$ & $68.6^{\mathrm{a}}$ \\
\hline Thr & $82.0^{\mathrm{c}}$ & $70.6^{\mathrm{a}}$ & $75.0^{\mathrm{ab}}$ & $68.7^{\mathrm{a}}$ & $73.8^{\mathrm{a}}$ \\
\hline Arg & $91.3^{\mathrm{b}}$ & $90.3^{\mathrm{b}}$ & $91.3^{\mathrm{b}}$ & $87.4^{\mathrm{a}}$ & $87.7^{\mathrm{a}}$ \\
\hline His & $82.6^{\mathrm{b}}$ & $75.8^{\mathrm{a}}$ & $77.4^{\mathrm{ab}}$ & $76.4^{\mathrm{a}}$ & $79.3^{\mathrm{ab}}$ \\
\hline Ile & $84.0^{\mathrm{b}}$ & $71.1^{\mathrm{a}}$ & $74.4^{\mathrm{a}}$ & $69.4^{\mathrm{a}}$ & $73.1^{\mathrm{a}}$ \\
\hline Leu & $85.3^{\mathrm{c}}$ & $77.3^{\mathrm{ab}}$ & $79.5^{\mathrm{b}}$ & $73.0^{\mathrm{a}}$ & $78.2^{\mathrm{b}}$ \\
\hline Phe & $83.5^{\mathrm{b}}$ & $74.6^{\mathrm{a}}$ & $76.8^{\mathrm{ab}}$ & $71.5^{\mathrm{a}}$ & $75.4^{\mathrm{a}}$ \\
\hline Val & $82.6^{\mathrm{b}}$ & $71.3^{\mathrm{a}}$ & $75.4^{\mathrm{a}}$ & $69.7^{\mathrm{a}}$ & $72.6^{\mathrm{a}}$ \\
\hline Ala & $79.2^{\mathrm{c}}$ & $64.0^{\mathrm{a}}$ & $74.4^{\mathrm{bc}}$ & $66.4^{\mathrm{a}}$ & $70.5^{\mathrm{ab}}$ \\
\hline Asp & $85.8^{\mathrm{b}}$ & $77.5^{\mathrm{a}}$ & $80.8^{\mathrm{ab}}$ & $77.0^{\mathrm{a}}$ & $80.2^{\mathrm{a}}$ \\
\hline Cys & $86.3^{\mathrm{c}}$ & $75.8^{\mathrm{abc}}$ & $78.4^{\mathrm{bc}}$ & $66.4^{\mathrm{a}}$ & $71.6^{\mathrm{ab}}$ \\
\hline Glu & $89.5^{\mathrm{c}}$ & $83.5^{\mathrm{ab}}$ & $86.7^{\mathrm{bc}}$ & $82.5^{\mathrm{a}}$ & $84.2^{\mathrm{ab}}$ \\
\hline Gly & $79.2^{\mathrm{c}}$ & $74.8^{\mathrm{bc}}$ & $75.3^{\mathrm{bc}}$ & $66.3^{\mathrm{a}}$ & $72.0^{\mathrm{ab}}$ \\
\hline Pro & $86.3^{\mathrm{c}}$ & $77.1^{\mathrm{b}}$ & $74.6^{\mathrm{b}}$ & $77.0^{\mathrm{b}}$ & $65.8^{\mathrm{a}}$ \\
\hline Ser & $85.8^{\mathrm{c}}$ & $75.8^{\mathrm{ab}}$ & $79.9^{\mathrm{b}}$ & $72.1^{\mathrm{a}}$ & $77.2^{\mathrm{ab}}$ \\
\hline Tyr & $80.63^{\mathrm{b}}$ & $69.4^{\mathrm{a}}$ & $68.8^{\mathrm{a}}$ & $68.4^{\mathrm{a}}$ & $72.1^{\mathrm{a}}$ \\
\hline
\end{tabular}

a, b, c - values in rows destignated with different letters differ significantly at $\mathrm{P}<0.05$

TABLE 7

Mean coefficients of standardized ileal digestibility of protein and amino acids in soyabean meal, field bean and pea seeds

\begin{tabular}{lcccccccccc}
\hline Item & Protein & Lys & Met & Thr & Ile & Leu & Val & His & Arg & Phe \\
\hline Soyabean meal* & 87 & 89 & 90 & 86 & 88 & 87 & 87 & 90 & 93 & 89 \\
Soyabean meal & 96 & 91 & 93 & 92 & 90 & 90 & 91 & 84 & 95 & 87 \\
Field bean* & 77 & 82 & 66 & 77 & 80 & 78 & 77 & 80 & 89 & 75 \\
$\quad$ Nadwiślański & 80 & 81 & 73 & 79 & 75 & 78 & 78 & 76 & 88 & 72 \\
$\quad$ Kodam & 79 & 80 & 64 & 79 & 76 & 78 & 78 & 71 & 87 & 72 \\
$\quad$ Martin & 79 & 78 & 69 & 76 & 73 & 76 & 75 & 69 & 87 & 69 \\
$\quad$ Optimal & 81 & 81 & 67 & 81 & 77 & 79 & 80 & 74 & 87 & 73 \\
Pea* & 79 & 81 & 74 & 76 & 80 & 78 & 77 & 81 & 89 & 77 \\
$\quad$ Piast & 85 & 87 & 76 & 81 & 78 & 82 & 80 & 77 & 93 & 79 \\
$\quad$ Rola & 86 & 89 & 76 & 84 & 81 & 84 & 83 & 79 & 94 & 81 \\
$\quad$ Idol & 82 & 84 & 71 & 78 & 76 & 77 & 77 & 78 & 90 & 75 \\
$\quad$ Wiato & 85 & 87 & 77 & 84 & 80 & 82 & 81 & 81 & 90 & 79 \\
\hline
\end{tabular}

* coefficients of standardized ileal digestibility according to Degussa (2001) 


\section{DISCUSSION}

The ileal digestibility of field beans and of peas was in agreement with the results reported by Grala et al. (1993), Degussa (2001), Mariscal-Landin et al. (2002) and Selgado et al. (2002a,b), among others, whereas the digestibility of lysine, methionine and threonine in our experiment was several percentage points lower. The differences in the digestibility of amino acids may have resulted from the use of different varieties of legumes (different chemical composition) and the age of the experimental animals.

The ileal digestibility of field bean and pea protein was significantly lower than in soyabean meal, which may have been an effect of the antinutrients contained in them (Abrahamsson et al., 1993; Grala et al., 1993; Jansman, 1993; Selgado et al., 2002a). The tannin level (Tabel 1) was higher in the coloured-flowered varieties of peas than in the white-flowered ones. Despite this, only the digestibility of cv. Idol peas, which have coloured flowers, was significantly lower than that of the while-flowered varieties. The tannin level of field beans did not differ among varieties and was relatively high. The low digestibility of proline found also in peas may have been related to the considerable excretion of a proline-rich protein in saliva. Jansman (1993) points to the negative influence of tannins on the availability of proline in rats fed high-tannin diets. This is explained by the ease with which the hydroxyl groups of phenolic compounds bind with groups in the relaxed structure of proline, resulting in a reduction of the antinutritive effect of tannins (Grala et al., 1993).

Fibre may also reduce digestibility as the result of adsorption of amino acids and binding of digestive enzymes (Sauer and Ozimek, 1986; Mosenthin et al., 1993; Selgado et al., 2002a). This component also has an exceptionally strong water-binding property, which may lead to accelerated digesta passage through the small intestine and reduction of feed digestibility (Grala et al., 1999). Some authors have found a negative correlation between both the fibre content of feeds and the amount of protein bound with fibre and the intestinal digestibility of protein and amino acids in pigs (Gdala et al., 1992; Fan et al., 2001). It should be stressed that the fibre content of the control feed was lower than in the experimental feeds (Table 4). A reason for the lower digestibility of peas may have also been the presence of considerable amounts of non-starch polysaccharides (NSP) having a low digestibility (hemicellulose, cellulose, pectins). Jondreville et al. (1992) and Le Guen et al. (1995a,b) point out that starch in peas is resistant to amylolytic enzymes.

The low digestibility of methionine found both in this study and by other authors (Mosenthin et al., 1993; Frankiewicz, 1999), may be related to the relatively low content of this amino acid in field beans and peas, and consequently, in the experimental feeds. 
No differences were also found between soyabean meal and the pea and field bean cultivars in the digestibility of those amino acids whose concentration in the experimental feeds (or seeds) was similar or higher than in the control feed. No statistically significant differences were found among varieties of field beans in the digestibility of protein and amino acids, which results from the similar chemical composition and lack of differences in antinutrient contents.

Despite the differences in the tannin contents among the white- and colouredflowered pea varieties, significant differences in apparent protein and lysine digestibility occurred only between one white-flowered (Rola) and coloured-flowered (Idol) variety of peas.

The determined ileal digestibility coefficients are coefficients of apparent digestibility since they do not factor in endogenous nitrogenous compounds. Many factors influence nutrient digestibility of various feeds and the amount of endogenous nitrogenous compounds. These include the protein and fibre levels of the ration, its antinutrient content, and the method of determination (Grala et al., 1998). Sauer and Ozimek (1986) consider however, that the nutritional value of feeds determined on the basis of apparent digestibility coefficients is sufficient in pig feeding practice.

The calculated standardized digestibility coefficients of the feeds studied by us are similar to those given by Degussa (2001) and differentiate to a smaller degree the legume varieties in terms of protein and amino acid digestibility than do coefficients of apparent digestibility.

\section{CONCLUSIONS}

The apparent ileal digestibility of protein and amino acids of field beans and of peas are lower that those of soyabean oilmeal and do not differ among field bean cultivars. Differences in digestibility of pea varieties are not unequivocally dependent on their tannin contents. 


\section{REFERENCES}

Abrahamsson M., Graham H., Dandanell Daveby Y., Aman P., 1993. Ileal and faecal digestibility of light-or dark-coloured peas (Pisum sativum) in growing pigs. Anim. Feed Sci. Tech. 42, 15-24

AOAC, 1996. Official Methods of Analysis, Association of Official Analytical Chemists. $16^{\text {th }}$ Edition. Washington, DC

Degussa, 2001. Standardized Ileal Digestibility of Amino Acids in Pigs. The Natherlands

Fan M.Z., Sauer W.C., Li S., 2001. Variability of apparent ileal amino acid digestibility in high-protein wheat samples for growing-finishing pigs. J. Anim. Feed Sci. 10, 103-118

Frankiewicz A., 1999. Amino acids ileal digestibility of protein feeds as the basis for diet formulation for growing pigs. Roczn. Akad. Rol. Pozn., Rozpr. Nauk. No. 296

Gdala J., Buraczewska L., Grala W., 1992. The chemical composition of different types and varieties of pea and the digestion of their protein in pigs. J. Anim. Feed Sci. 1, 71-79

Grala W., Buraczewska L., Wasilewko J., Verstegen M.W.A., Tamminga S., Jansman A.J.M., Huisman J., Korczyński W., 1998. Flow of endogenous and exogenous nitrogen in different segments of the small intestine in pigs fed diets with soyabean concentrate, soyabean meal or rapeseed cake. J. Anim. Feed Sci. 7, 1-20

Grala W., Jansman A.J.M., van Leeuwen P., Huisman J., van Kempen G.J.M., Verstegen M.W.A., 1993. Nutritional value of faba beans (Vicia faba L.) fed to young pigs. J. Anim. Feed Sci. 2, 169-179

Grala W., Verstegen M.W.A., Jansman A.J.M., Huisman J., van Leeuwen P., Tammiga S., 1999. Effects of ileal endogenous nitrogen losses and dietary amino acid supplementation on nitrogen retention in growing pigs. Anim. Feed Sci. Tech. 80, 207-222

Jansman A.J.M., 1993. Tannins in faba bean (Vicia faba L.) - anti-nutritional properties in monogastric animals. PhD. Thesis, Department of Animal Nutrition, Wageningen Agricultural University, and TNO - Toxicology and Nutrition Institute, Department of Animal Nutrition and Physiology (ILOB), Wageningen (The Netherlands)

Jondreville C., Broeke J., van der Gatel F., Cauwenberghe S., 1995. Ileal digestibility of amino acids in feedstuffs for pigs. ITCF, Eurolysine 52 (France)

Jondreville C., Grosjean F., Buron G., Peyronnet C., Beneytout J.L., 1992. Comparison of four pea varieties in pig feeding through digestibility and growth performance results. J. Anim. Physiol. Anim. Nutr. 68, 113-122

Kuhla S., Ebmeier C., 1981. Unterschungen zum Tanningehalt in Ackerbohnen. Arch. Tierenähr. 31, 573-588

Leeuwen van P., Kleef van D., Kempen van G.J.M., Huismann J., Verstegen M.W.A., 1991. The post valve T-caecum canniulation technique in pigs applicated to determine the digestibility of amino acid in maize, groundnut and sunflower meal. J. Anim. Physiol. Anim. Nutr. 65, 183-193

Le Guen M.P., Huisman J., Verstegen M.W.A., 1995a. Partition of the amino acids in ileal digesta from piglets fed pea protein diets. Livest. Prod. Sci. 44, 169-178

Le Guen M.P., Huisman J., Gueguen J., Beelen G., Verstegen M.W.A., 1995b. Effects of a concentrate of pea antinutritional factors on pea protein digestibility in piglets. Livest. Prod. Sci. 44, 157-167

Mariscal-Landin G., Lebreton Y., Sève B., 2002. Apparent and standarised true ileal digestibility of protein and amino acids from faba bean, lupin and pea, provided as whole seeds, dehulled or extruded in pig diets. Anim. Feed Sci. Tech. 97, 183-198

Mosenthin R., Sauer W.C., Lien K.A., Lange de C.F.M., 1993. Apparent, true and real protein and amino acid digestibilities in growing pigs fed two varieties of faba beans (Vicia faba L.) different in tannin content. J. Anim. Physiol. Anim. Nutr. 70, 253-265 
NRC, 1998. Nutrient Requirements of Swine. 10 $0^{\text {th }}$ Edition. National Academy Press, Washington, DC

Saha D.C., Gilbreath R.L., 1991. Analytical recover of chromium diet and faeces determined by colorimetry and atomic absorption spectrophotometry. J. Sci. Food Agr. 55, 433-446

Sauer W.C., Ozimek L., 1986. Digestibility of amino acid in swine: Results and their practical applications - A review. Livest. Prod. Sci. 15, 367-388

Selgado P., Martins J.M., Carvalho F., Abreu M., Freire J.P.B., Toullec R., Lalles J.P., Bento O., 2002a. Component digestibility of lupin (Lupinus angustifolius) and pea (Pisum sativum) seeds and effects on the small intestine and body organs in anastomosed and intact growing pigs. Anim. Feed Sci. Tech. 98, 187-201

Selgado P., Freire J.P.B., Mourato M., Cabral F., Toullec R., Lalles J.P., 2002b. Comparative effects of different legume protein sources in weaned piglets: nutrient digestibility, intestinal morphology and digestive enzymes. Livest. Prod. Sci. 74, 191-202

Wiatr K., 1999. Faba bean. Varieties Experimental Results (in Polish). Centralny Ośrodek Badania Odmian Roślin Uprawnych. No. 1150. Słupia Wielka. ISSN 1232-0927 (Poland)

\section{STRESZCZENIE}

\section{Pozorna i standaryzowana strawność jelitowa bialka oraz aminokwasów wybranych odmian bobiku i grochu u rosnących świń}

Oznaczono pozorną jelitową strawność białka i aminokwasów nasion bobiku odmian Nadwiślański, Kodam, Martin i Optimal oraz grochu odmian Piast, Rola, Idol i Wiato metodą wskaźnikową, stosując $\mathrm{Cr}_{2} \mathrm{O}_{3}$ jako wskaźnik. Badania przeprowadzono w układzie dwóch kwadratów łacińskich $(5 \times 5$ i $4 \times 4)$ na 9 wieprzkach o początkowej masie ciała około $25 \mathrm{~kg}$ z prostymi kaniulami (kaniula T) założonymi do końcowego odcinka jelita biodrowego. W mieszankach doświadczalnych jedyne źródło białka stanowiły nasiona bobiku lub grochu, w grupie kontrolnej poekstrakcyjna śruta sojowa. Strawność białka i większości aminokwasów bobiku i grochu była istotnie niższa $(\mathrm{P}<0,05)$ niż śruty sojowej. Nie stwierdzono istotnych różnic $(\mathrm{P}>0,05)$ w strawności białka i aminokwasów pomiędzy badanymi odmianami bobiku. Istotne różnice $(\mathrm{P}<0,05)$ w strawności białka i niektórych aminokwasów stwierdzono pomiędzy odmianą grochu biało- i kolorowo kwitnącego.

Obliczono standaryzowaną strawność białka i aminokwasów nasion badanych odmian bobiku oraz grochu. Współczynniki strawności standaryzowanej były nieco wyższe niż pozornej strawności jelitowej. 